\title{
Sustainability of Climate Change Adaptation Practices in South-Western Coastal Area of Bangladesh
}

\author{
Md. Humayain Kabir ${ }^{1} \&$ Mohammed Abdul Baten ${ }^{2}$ \\ ${ }^{1}$ Institute of Forestry and Environmental Sciences, University of Chittagong, Bangladesh \\ ${ }^{2}$ Department of Environmental Science and Management, Independent University, Bangladesh \\ Correspondence: Md. Humayain Kabir, Institute of Forestry and Environmental Sciences, University of \\ Chittagong, Bangladesh. Tel: +88-01712967191.E-mail: mhkabir@cu.ac.bd
}

Received: December 24, 2018

doi:10.5539/jsd.v12n5p1

\author{
Accepted: January 23, 2019 \\ Online Published: September 29, 2019 \\ URL: https://doi.org/10.5539/jsd.v12n5p1
}

\begin{abstract}
In Bangladesh, South Western (SW) coastal area is the most vulnerable due to its geo-morphological characteristics and socio-economic conditions. Consequently, this study aims at find out the sustainable adaptation practices to climate change impacts through a series of field study along with questionnaire survey and reviewing the secondary literature. The study shows that near about 50 adaptation practices are exercised in SW coastal area of Bangladesh. Among these, growing local rice variety, rainwater harvesting, directly use of pond water through proper pond management, raising plinth, lowering use roof etc. are the more sustainable adaptation practices. On the other hand, homestead gardening, dyke nursery, cropping on raised mound, school cum cyclone shelter, purification of pond water trough traditional knowledge are the moderately popular and sustainable adaptation practices in terms of social, economic and environmental aspects. Furthermore, shrimp cultivation at homestead, fish-vegetables combined cultivation, purification of pond water through govt. supported filter, pond filter, bamboo made piling house etc. are the less sustainable one.
\end{abstract}

Keywords: climate change adaptation, Bangladesh, coastal areas, sustainability

\section{Introduction}

Global climate change has been one of the most talked about issues in recent times. Climate scientists declare that climate change is happening and is the biggest threat ever faced by the humanity (IPCC, 2007; Met Office, 2011). With this regard, Bangladesh is one of the most vulnerable countries to climate change due to a number of hydrological, geological and socio-economic factors. Furthermore, increased and longer periods of floods and erosion in monsoon, and rising sea level, increased drought due to reduced rainfall in winter and cyclones and tropical storms accelerate this situation (Chowdhury, 2011).

Through a careful multi-criteria analysis it was found that the South-Western coastal region of the country is the most vulnerable area to climate change impacts (BCAS-RA-Approtech, 1994). The future prediction shows that an increase in monsoon rainfall would increase flood vulnerability of the region. On the other hand, in dry-season, low and diminishing rainfall would enhance possibility for increasing drought vulnerability and salinity ingress along the coastal river systems (Alam et al., 1998; Ahmed et al., 1998a). Simultaneously, inundation of low-lying unprotected coastal areas, due to a combined effect of gradual subsidence and a rise in sea level, would enhance the possibility for saline water-logging throughout the southwestern region. World Bank (2000) reported that the above mentioned changes would have severe adverse impacts on coastal resources, water resources, agriculture, human health and biodiversity, with special reference to the south western region of Bangladesh.

As response to adverse effects of climate change, Bangladesh could consider both mitigation and adaptation which were highlighted in the UNFCCC. However, the country's greenhouse gases emission being very negligible compared to other developed countries, it was rather obvious that there had been increasing emphasis on adaptation. Moreover, the Bangladeshi has been widely known for their strong social will and mental strength for coping with climate-related extreme events. That is why, for a nation known for their fighting abilities, adapting to climate change has been a natural choice (Ahmed, 2010). Since climate change cannot be totally avoided and can more than exist, consequently, climate change adaptation brings immediate benefits and 
opportunities foster the local community to go for adaptation practices in Bangladesh (Burton, 1996).

Following the signing of the UNFCCC, concerned research communities had begun to emphasize on adaptive responses, particularly on anticipatory and planned adaptation (Abramovitz et al., 2002; Adger, 2001). In view of growing needs for adaptation and people's strong willingness to respond to climate related hazards, the first ever project titled 'Reducing Vulnerability to Climate Change (RVCC)' was designed in 2002 and implemented until the beginning of 2005 .

Within its limited resources, Government of Bangladesh has responded to the climate change problems conspicuously. Over the couple of years, both nationally and internationally, Bangladesh has been identified as one of the pioneers who started mainstreaming climate change into broader governance spectrum. Evidently, Bangladesh prepared National Adaptation Programme of Action (NAPA) in 2005; and subsequently in 2009 the country formulated most comprehensive climate action guidelines named Bangladesh Climate Change Strategy and Action Plan (BCCSAP). To operationalize the BCCSAP, Bangladesh has formed 'Climate Change Trust Fund (CCTF)' with its own resources. All the actions taken in response to climate change clearly signify the country's commitment to reduce vulnerability and secure the livelihood of its large population base. In addition to all of these, Media campaign (radio, TV, print media, round table discussion), setting up eco-clubs (village level clubs, sharing and learning sessions by experts, drama, cultural function), school program (a complete school curriculum on climate change, student initiatives, teacher's initiatives), folk media (Pot song, drama, Baul song), information collection and dissemination (booklets, paper clippings, monthly news letter, climate change cell, library), voice raising at grassroots level (credit group formation, water (pani) committee, posters) etc. are some activities for awareness raising about climate change adaptation in south western coastal area of Bangladesh (Ahmed, 2010).

\subsection{Objectives of the Study}

Overall objective of the study is to search the sustainability of existing adaptation practices to climate change in South-Western (SW) coastal area of Bangladesh.

Specific objectives of the study are:

1) To list down the existing adaptation practices to climate change in South-Western coastal area of Bangladesh.

2) To search the sustainable adaptation practices of climate change in SW coastal area of Bangladesh.

\section{Concept of Adaptation}

The tern adaptation comes from the word 'adapt meaning that making the current situations through altering the original one to more suitable. In other words, 'adaptation' can be defined as the process of adapting and the situations of being adjusted (Smit et al. 2000). Simply, climate change adaptation is denoted as the process of all adjustments in behavior or economic structure, including its short term and long term effects, by which the vulnerable people adaptation to climate change is the process through which people cut the adverse effects of climate change both on the human health and social welfare, and hence take the maximum opportunities that the ambient environment provides (Smit, 1993, Smit et al., 1996, Burton, 1992; Burton, 1997). IPCC (2007) defined adaptation as 'adjustment in natural or built environment in response to observed and predicted climatic stimuli or their negative effects, which moderates harm or exploits all the useful opportunities. Adaptation can be broadly categorized as anticipatory, autonomous and planned adaptation (Watson et al., 1996).

\subsection{Concept of Sustainability}

Ecologically, the term sustainability is defined as a system which can survive or persist (Costanza and Patten, 1995). On the other hand, biologically, this refers to the avoidance of extinction, and living for the survival and reproduction. Economic point of view, it refers to avoiding major disruptions and collapses, hedging against instabilities and discontinuities. Simply, sustainability, at its base, is always concerns temporality, and, in particular, longevity. More formally, this aspect of sustainability can be thought of in terms of the system and it's component part's longevity (Costanza \& Patten 1995). 
Table 1. Indicators of sustainability

\begin{tabular}{|c|c|}
\hline Sustainability indicators & Source \\
\hline -Social security system & \multirow{5}{*}{$\begin{array}{l}\text { Hans-Boeckler-Foundation } \\
2001\end{array}$} \\
\hline -Equal opportunities & \\
\hline -Enabling of social innovation and work type construction & \\
\hline -Safeguarding the basis for satisfying material needs & \\
\hline $\begin{array}{l}\text {-Full employment, social security, fair distribution of burdens between } \\
\text { generations }\end{array}$ & \\
\hline -Basic supply & \multirow{4}{*}{ Jörissen et al. 1999} \\
\hline -Independent security & \\
\hline -Equal opportunities & \\
\hline -Social resources & \\
\hline -Participation & \multirow{2}{*}{ Empacher and Wehling, 1999} \\
\hline -Cultural diversity & \\
\hline Health, Social security, Social Integration, Gender equity, Justice & Littig, 2001 \\
\hline Environmental, economic, social and institutional & UNCSD, 2001 \\
\hline Social and policy relevance (economic viability, social structure, etc.). & \multirow{6}{*}{ Nambiar et al., 2001} \\
\hline Analytical soundness and measurability. & \\
\hline Suitable for different scales & \\
\hline Encompass ecosystem processes and relate to process oriented modelling. & \\
\hline Sensitive to variations in management and climate. & \\
\hline Accessibility & \\
\hline Effectiveness, efficiency, equity and legitimacy & Adger, et al., 2005 \\
\hline $\begin{array}{l}\text { Central concerns about sustainability-economic, social and environmental } \\
\text { dimensions }\end{array}$ & Beg, et al., 2002 \\
\hline
\end{tabular}

Table 2. Objectivity criteria of sustainability indicators

\begin{tabular}{ll}
\hline Indicators should & Source \\
\hline Be accurate and bias free & UNCCD, 1994; Breckenridge et al, 1995 \\
\hline Be liable and consistent over space and time & $\begin{array}{l}\text { Breckenridge et al, 1995; Abbot and Guijt, 1997; Rubio } \\
\text { and Bochet, 1998 }\end{array}$ \\
\hline Assess trends over time & $\begin{array}{l}\text { UNCCD, 1994; Breckenridge et al, 1995; Rubio and } \\
\text { Bochet, 1998; UK Government, 1999 }\end{array}$ \\
\hline Provide early warning of detrimental change & $\begin{array}{l}\text { Breckenridge et al, 1995; Rubio and Bochet, 1998; Zhen } \\
\text { and Routray, 2003 }\end{array}$ \\
\hline Be representative of system variability & $\begin{array}{l}\text { Breckenridge et al, 1995, Krugmann, 1996; UK } \\
\text { Government, 1999 }\end{array}$ \\
\hline Provide timely information & $\begin{array}{l}\text { UNCCD, 1994; Breckenridge et al, 1995; Abbot and Guijt, } \\
\text { 1997 }\end{array}$ \\
\hline Be verifiable and replicable & UNCCD, 1994; Abbot and Guijt, 1997 \\
\hline Be scientifically robust and credible & Rubio and Bochet, 1998, UK Government, 1999 \\
\hline Be relevant to the local system/environment & Mitchell et al., 1995 \\
\hline $\begin{array}{l}\text { Sensitive to system stresses or the changes it is } \\
\text { meant to indicate }\end{array}$ & \begin{tabular}{l} 
UK Government, 1999 and Zhen and Routray, 2003 \\
\hline $\begin{array}{l}\text { Have a target level, baseline or threshold against } \\
\text { which to measure them }\end{array}$
\end{tabular} \\
\hline UK Government, 1999 and Zhen and Routray, 2003
\end{tabular}




\subsection{Frameworks on Sustainability}

\subsubsection{The Triple Bottom Line}

The scientists and practitioners of "the triple bottom line" believe that sustainability decisions made not only on the basis of economic benefits but also on environmental protection and social equality. The three elements of the triple bottom lines economic, environmental and socials can be combined. Eco-efficiency refers to the optimizing economic and environmental goals whereas fair trade refers to economic activities conducted with particular attention to social consequences. On the other hand, environmental justice refers to social equity with respect to environmental protection (Elkington, 1998). However, a group of scientists opined that this 'The Triple Bottom Line' framework lack of a solid scientific foundation.

\subsubsection{The Natural Step}

The Natural Step defines a 'sustainable society' in different ways. Firstly, the nature is not capable to systematically increase the resources derived from the earth system. Secondly, natural environment is not subject to rise the concentrations of resources produced by the society. Thirdly, nature is susceptible to unchecked anthropogenic degradation due to meet the basic needs of human being (Nattrass \& Altomare, 1999). In recent era, several current practices are unsustainable. Some examples include the increased combustion of fossil fuels which increases concentrations of atmospheric carbon dioxide; unregulated emissions of persistent organic and inorganic chemicals; radical change of forestland and water bodies; and a rapid growth of population.

\subsubsection{The Ecological Footprint}

The Ecological Footprint (EF) compares the environmental impact of specific actions to the limited earth's natural resources and the functions of ecosystem. The EF calculates a ratio of "how many earths" would be required to provide enough biologically productive land area to maintain the flows of resources and wastes in a sustainable manner, if everyone lived like a specific person or group of people (Wackernagel \& Rees, 1996). The EF has been implemented across a wide range of units of analysis, including a consumer product (e.g., a personal computer, washing detergent); an individual company; an economic sector; specific regions and nations; and the entire earth system (Frey et al., 2000). Urban economists around the world have used the EF to evaluate the environmental impacts of commuting in Barcelona, Spain, as a function of transportation technology and residents' locations (Muniz \& Galindo, 2001).

\subsubsection{Graedel and Klee's Sustainable Emissions and Resource Usage}

Graedel and Klee (Graedel and Klee, 2002) proposed a four-step process for measuring the sustainability in terms of natural resource use. These are: (i) calculation of the availability and supply chain of materials; (ii) allocation of consumption of this supply over a specific time scale and population; (iii) accounting for the recycling and for existing stockpiles including landfills; and (iv) consideration of this rate to be the maximum sustainable consumption rate and compare it to the current usage rate.

\subsection{The Need for Adaptation Indicators}

There is unequivocal evidence that climate change is happening and its' adverse impacts are experiencing by the global communities including Bangladesh. These impacts are expected to become more severe as changes in climate variability and weather extremes in the near future. A major challenge for policy makers at different scales of governance is to understand how, where and in what form of the projected impacts of climate change will occur. This task is complicated by a number of factors, not least being that the relationship between changes in climatic variables (e.g. changes in precipitation), impacts (e.g. increased flooding) and system response (e.g. adaptive capacity) is far from clear (Harley et al., 2008). There is therefore a need for all countries, developed and developing, to adapt to climate change. Adaptation offers an ample of opportunities to build resilience to climate change. Adaptation indicators are so useful for evaluating adaptation funding and policy interventions, future policy development, and disseminating adaptation techniques to the general public. All of these acts a substantial input for the politicians for the global climate change negotiations.

There is also a growing demand from the different stakeholders to share information on good climate change adaptation practices and hence to measure the progress and effectiveness of resource commitments (e.g. assessment and monitoring of long-term investments in infrastructure to accommodate the growing risks of weather and climate extremes). A further role for indicators is, therefore, as a communications tool to raise awareness in the policy community and among practitioners. For this reason, indicators should be as transparent as possible (Harley et al., 2008). 
Adaptation indicators can be divided into two groups. These are Process Based Indicators and Outcome Based Indicators. A process-based approach can be defined as the key stages required in a process that would pint the best choice for the end point. In simple words, this is 'upstream' process that provides the enhanced capacity to handle a wide range of outcomes. Relevant indicators used in this process are needed to inform and justify the decisions taken and to contribute substantially to the policymakers to go ahead more strategically and proactively. On the other hand, an outcome-based approach can be defined as an explicit outcome of the adaptation practice i.e. improved drainage facility to cope with the excessive rainfall events. In other words, it also is called as 'downstream' approach that emphasize on the effectiveness of adaptation policies and legislation for a long run considering the future climate (Harley et al., 2008).

\section{Methodology}

\subsection{Description of the Study Area}

The southwest coastal region of Bangladesh (Figure 1) is under the scope of this study. The southwest coastal region of Bangladesh is an active part of Ganges Delta formed by alluvial soil carried in by the upstream flows. Most of the parts of this region (about $70 \%$ of the total landmass) are coastal wetlands by nature that are connected with many estuarine rivers of the Bay of Bengal. The region is protected from tidal surge by the Sundarbans mangrove forest. Cyclones, tidal surges, foods, repeated water-logging and land subsidence are common in this part of Bangladesh, shaping the live and livelihood patterns of the people living in the area. The southwest coastal region has been identified as one of the parts of the world most vulnerable to the effects of a rise in sea level caused by climate change.

\subsection{Sampling Procedure}

Among the six districts of South-Western coastal area, Khulna was selected purposively for this study. From Khulna district 2 Upazilas namely Koyra and Paikgacha were selected through simple random sampling. Koyra sadar, Amadi and Chandkhali union were selected from these Upazilas randomly. From these unions, five villages namely Koyra 5 no., Nonadighir par, Naksa, Harinager and Chandkhali were also selected following simple random sampling. Finally, a total of 100 households were selected randomly for this study. This overall sampling design follows the multi-stage sampling.

\subsection{Data Collection}

Both primary and secondary data were collected to conduct this study. During the field visit, Key Informant Interview (KII) and three focus group discussions (FGDs) were conducted at Koyra 5 no., Harinagar and Nana Dighir par (Munda community) with the members of the local forest people's associations coordinated by Unnayan Onneshan-The Innovators. In addition to this, open discussion was also made on the climate change adaptation in this area. A structured questionnaire containing social, economic and environmental aspect of existing adaptation practices was used to collect data.

\subsection{Method of Calculating Sustainability of Climate Change Adaptation}

There are three Multi Criteria Decision Making (MCDM) methodologies that could be used in criteria and indicators (C\&I) assessment: (1) pairwise comparisons; 2) ranking and (3) rating. In a nutshell, the pairwise comparisons approach distills the complex C\&I decision problem into a series of one-on-one judgment on the significance of each pair of indicator relative to one criterion. Ranking, on the other hand, is different from the pairwise comparison method in those C\&I elements are not compared one-on-one. Instead, they are judged by their degrees of importance and are then given ranks accordingly. Finally, the rating method is like the ordinal ranking method in that all indicators are judged by their relative degrees of importance indicated by 'scores' instead of cardinal rank (Mendoza \& Prabhu, 2000). 

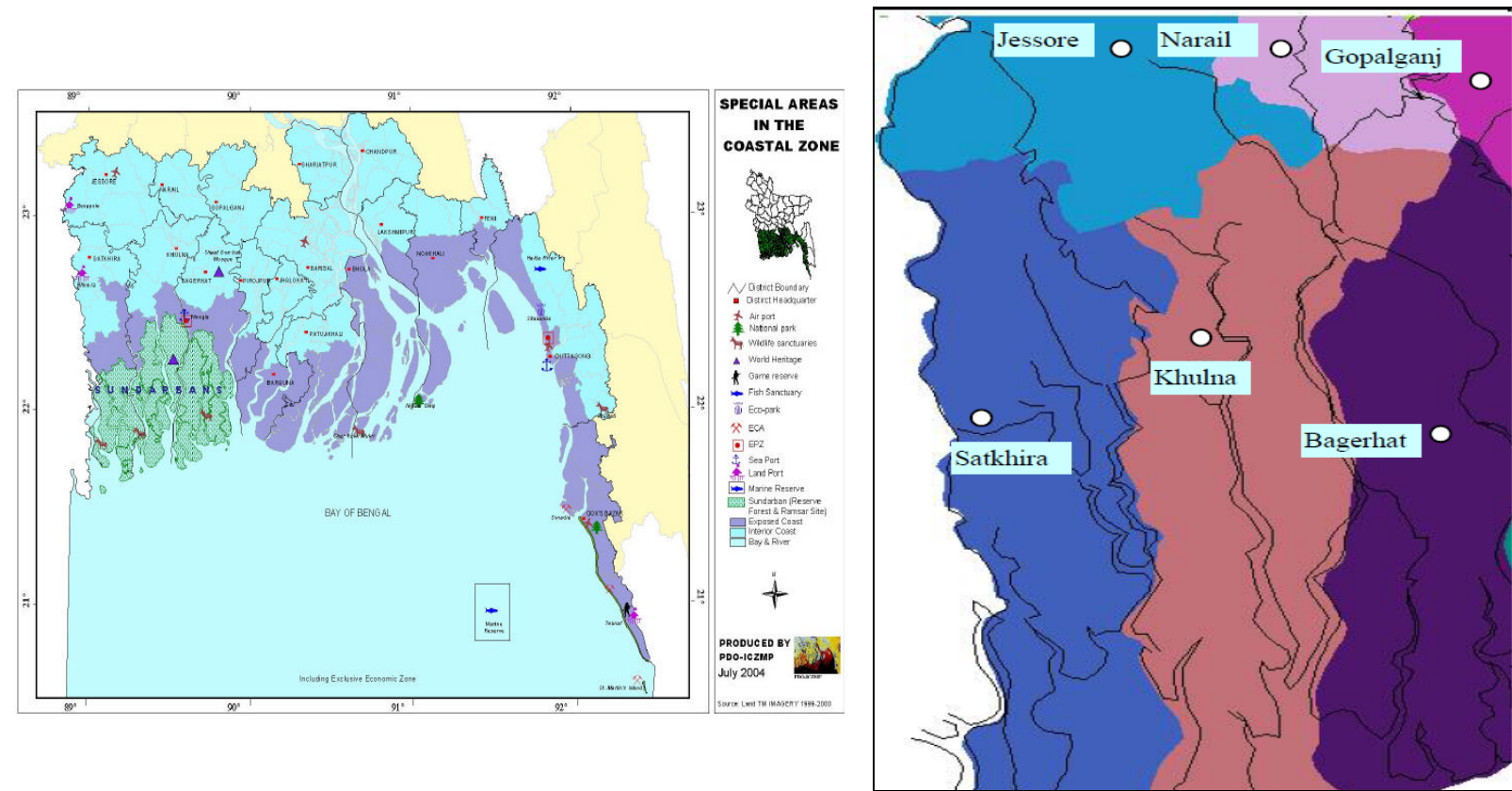

Figure 1. Map of the South-Western coastal area of Bangladesh (Source: PDO-ICZM)

In this study, rating method was used to calculate the sustainable adaptation practices. Although in this method, total scores are distributed by 100 , but in this calculation, a total score of 10 used instead of 100. Scorings were used both of the social, economic and environmental aspects. The total average scores were taken into consideration for decisions about the sustainable adaptation practices.

\section{Results and Discussion}

\subsection{List of Existing Adaptation Practices in SW Coastal Area of Bangladesh}

The local people of South-Western coastal area are struggling against the adverse climate change impacts for a long time. Since it is not possible for that people to mitigate this effect, therefore, adaptation to climate change impacts is their natural choice. All the existing adaptation practices (Table 3) are categorized on the basis of sector-wise, seasonality and promoter-based (Table 4). We found that livelihood related adaptation was 29 $(64.4 \%$ ) while about 69\% was wet seasonal adaptation (Figure $2 \mathrm{a}$ and $2 \mathrm{~b}$ ).

Table 3. Comprehensive list and description of climate change adaptation practices in southwestern Bangladesh

\begin{tabular}{|c|c|c|c|c|}
\hline Name of Practice & Location & Brief Description & $\begin{array}{l}\text { Nature of } \\
\text { Adaptation }\end{array}$ & Objective \\
\hline CMAS Culture & $\begin{array}{l}\text { The practice scattered in } \\
\text { Sarankhola Upazila of } \\
\text { Bagerhat District , Koyra } \\
\text { Upazila of Khulna District and } \\
\text { Assasuni Upazila of Satkhira } \\
\text { District }\end{array}$ & $\begin{array}{l}\text { Combined cultivation of some mangrove } \\
\text { plant species like Goalpata, Keora and a few } \\
\text { aquatic species like Bagda Telapia, Perse, and } \\
\text { Vetki etc. on fresh or brackish water swampy } \\
\text { land }\end{array}$ & $\begin{array}{l}\text { Livelihood } \\
\text { (Crop cultivation) }\end{array}$ & $\begin{array}{l}\text { Adaptation to cyclone, } \\
\text { tidal surge and salinity }\end{array}$ \\
\hline Grass Cultivation & $\begin{array}{l}\text { Tala, Assasuni and Shymnagar } \\
\text { (Gabura Union) Upazila of } \\
\text { Satkhira District }\end{array}$ & $\begin{array}{l}\text { Cultivation of Napier Grass (locally called } \\
\text { Bajo Grass) alongside ponds and wetlands }\end{array}$ & $\begin{array}{l}\text { Livelihood (Crop } \\
\text { cultivation) }\end{array}$ & Adaptation to Salinity \\
\hline Keora Nursery & $\begin{array}{l}\text { Protabnagar Union of Assasuni } \\
\text { Upazila under Satkhira District } \\
\text { and scattered practice in Koyra } \\
\text { Upazila of Khulna District }\end{array}$ & $\begin{array}{l}\text { Collecting Keora seeds from the Sundarbans } \\
\text { and growing Keora plants with much care for } \\
\text { plantation in homestead surrounding fallow } \\
\text { lands, low lands and dykes of agricultural } \\
\text { lands. }\end{array}$ & $\begin{array}{l}\text { Livelihood } \\
\text { (Agriculture) }\end{array}$ & $\begin{array}{l}\text { Adaptation to cyclone, } \\
\text { tidal surge and very high } \\
\text { salinity }\end{array}$ \\
\hline
\end{tabular}


Borodol Union of Assasuni

Upazila, Khalishkhali and

Mele (Reed) Khesra union of Tala Upazila

Cultivation under Satkhira District and Chadkhali Union of Paikgachha Upazila of Khulna District
Cultivation of Mele in salinity rich areas where cultivation of crops of fresh water variety is impossible
Livelihood

(crop cultivation)
Adaptation to salinity, tidal flood and tidal surge
Dumuria and Koyra upazila of

Khulna District, Fakirhat

Dyke cropping Upazila of Bagerhat District , Tala and Assasuni Upazila of Satkhira District

5 no. Koyra \& 7 no. Uttar

Cage aquaculture Bedkashi unions of Koyra Upazila of Khulna District

Paikgacha Upazila, 7 no. Uttar Bedkashi Union of Koyra Upazila of Khulna District and Atulia, Gabura and Buri Goalini unions of Shymnagar Upazila under Satkhira District

Bagali and Koyra unions of Koyra Upazila, Dumuria Upazila and Paikgachha Upazila (Chandkhali Union) under Khulna District and Borodol Union of Assasun Upazila under Satkhira District

\begin{tabular}{ll}
\hline \multirow{2}{*}{ Hydroponics } & $\begin{array}{l}\text { Pirojpur District and } \\
\text { Sarankhola Upazila under } \\
\end{array}$ \\
& Bagerhat District \\
\hline & Koyra Upazila of Khulna \\
& District, Shymnagar Upazila of \\
Poultry farming & Satkhira District and \\
& Sarankhola Upazila of \\
& Bagerhat District
\end{tabular}

Cattle Raising
Shrimp-fish mixed
cultivation

Assasuni Upazila of Satkhira District and Sarankhola Upazila of Bagerhat District

Tala Upazila of Satkhira District, Dumuria and Koyra upazila (particularly Amadi, Bagali and Koyra unions) under Khulna District

\begin{tabular}{ll}
\hline Apiculture & $\begin{array}{l}\text { Shyamnagar Upazila of } \\
\text { Satkhira District }\end{array}$ \\
\hline & Koyra and Amadi unions of \\
& Koyra Upazila, Paikgacha \\
Goalpata & Upazila under Khulna District \\
Cultivation & and Sarankhola and Mongla \\
& upazila of Bagerhat District
\end{tabular}

Growing vegetables and spices on the dykes of agricultural lands, shrimp ghers and homestead fish ponds

Small scale fish particularly Bagda farming in cages at household or community level at water bodies (rivers, khals, beels)
Livelihood (family Adaptation to flood, income generation) waterlogging and salinity

Adaptation to breaking

Livelihood fish ponds banks by tidal

(Fish farming) and coastal flood.

Collecting immature and soft crabs from the creeks of the Sundarbans and rearing in a pond to fat and to put on weight until they Livelihood (crop cultivation)

Adaptation to Salinity

Cultivation of vegetables like bottle-gourd, pumpkin, seam, sweet pumpkin in hanging earthen pots and baskets

Livelihood

(Horticulture) Adaptation to flooding and salinity
Growing vegetables on floating beds in waterlogged areas
Livelihood

(Horticulture)
Adaptation to water logging and salinity
After about one year of Aila, rearing of poultry/duck at household level started again to level up family income and to meet the family demand of protein

\section{Livelihood}

(Seeking alternative options)
Adaptation

to

Raising cattle at household level to meet the need of protein and milk and to level up family income again started about one year after cyclone Aila

Shrimp-fish mixed cultivation in fresh water ponds and shrimp-fish mixed cultivation in saline water ponds both at household and community level

\section{Livelihood}

(Agriculture) waterlogging and salinity intrusion
Livelihood

(Seeking alternative option)
Adaptation to coastal and tidal flooding and waterlogging

$\begin{array}{lll}\text { Bee keeping and honey extraction } & \text { Livelihood } & \begin{array}{l}\text { Alternative } \\ \text { generation }\end{array}\end{array}$

Cultivation of Goalpata in river side floodplain lands or homestead surrounding ditches and low lands
Adaptation to salinity, tidal flood and storm surge 


\begin{tabular}{|c|c|c|c|c|}
\hline Keora Cultivation & $\begin{array}{l}\text { Koyra, Paikgachha (Suladana) } \\
\text { and Dacope upazila of Khulna } \\
\text { District }\end{array}$ & $\begin{array}{l}\text { Cultivation of Keora tree in the dykes of } \\
\text { farming lands and homestead surrounding } \\
\text { brackish water swampy lands }\end{array}$ & $\begin{array}{l}\text { Livelihood } \\
\text { (alternative income } \\
\text { generation) }\end{array}$ & $\begin{array}{l}\text { Adaptation to salinity, } \\
\text { tidal flood and storm } \\
\text { surge }\end{array}$ \\
\hline $\begin{array}{l}\text { Growing local rice } \\
\text { variety (BR 28) } \\
\text { cultivation by } \\
\text { crop calendar } \\
\text { adjustment }\end{array}$ & $\begin{array}{l}\text { Amadi and Bagali unions of } \\
\text { Koyra Upazila and Paikgachha } \\
\text { Upazila under the district of } \\
\text { Khulna and Gabura Union of } \\
\text { Shyamnagar Upazila under } \\
\text { Satkhira District }\end{array}$ & $\begin{array}{l}\text { Cultivating rice bypassing the flood season } \\
\text { particularly during the overlapping periods of } \\
\text { Kharif-1 \& Kharif-2 (May to mid August) } \\
\text { where flood usually occurs at late August. }\end{array}$ & $\begin{array}{l}\text { Livelihood } \\
\text { (food crop } \\
\text { cultivation) }\end{array}$ & $\begin{array}{l}\text { Adaptation to flood and } \\
\text { waterlogging }\end{array}$ \\
\hline $\begin{array}{l}\text { Local rice variety } \\
\text { (T Aus) } \\
\text { cultivation by } \\
\text { crop calendar } \\
\text { adjustment }\end{array}$ & $\begin{array}{l}\text { Amadi and Bagali unions of } \\
\text { Koyra Upazila, Paikgachha } \\
\text { Upazila and Dacope Upazila } \\
\text { (Gupalpur Union) under } \\
\text { Khulna District and Tala and } \\
\text { Kolaroa Upazila of Satkhira } \\
\text { District }\end{array}$ & $\begin{array}{l}\text { Cultivating rice bypassing the flood season } \\
\text { particularly during the overlapping periods of } \\
\text { Kharif-1 \& Kharif-2 (May to late August) } \\
\text { where flood usually occurs at late August. }\end{array}$ & $\begin{array}{l}\text { Livelihood } \\
\text { (Food crop } \\
\text { cultivation) }\end{array}$ & Adaptation to drought \\
\hline $\begin{array}{l}\text { Cropping on } \\
\text { raised mound }\end{array}$ & $\begin{array}{l}\text { Pirojpur District, Paikgachha } \\
\text { Upazila of Khulna and } \\
\text { Shymnagar Upazila of } \\
\text { Satkhira }\end{array}$ & $\begin{array}{l}\text { Growing different types of vegetables (guard, } \\
\text { bitter guard, ladies fingers, chilies, } \\
\text { cauliflowers, cabbages, radishes, etc) on } \\
\text { raised mound }\end{array}$ & $\begin{array}{l}\text { Livelihood } \\
\text { (Horticulture, } \\
\text { family income } \\
\text { generation) }\end{array}$ & $\begin{array}{l}\text { Adaptation to } \\
\text { waterlogging and salinity }\end{array}$ \\
\hline $\begin{array}{l}\text { Homestead } \\
\text { gardening }\end{array}$ & $\begin{array}{l}\text { Amadi and Bagali unions of } \\
\text { Koyra Upazila and Paikgachha } \\
\text { Upazila under Khulna District } \\
\text { and Borodol Union of } \\
\text { Assasuni Upazila under } \\
\text { Satkhira District have seen the } \\
\text { practice. }\end{array}$ & $\begin{array}{l}\text { Growing various types of vegetables (guard, } \\
\text { bitter guard, ladies fingers, chilies, } \\
\text { cauliflowers, cabbages, radishes, etc) on } \\
\text { raised homestead yards }\end{array}$ & $\begin{array}{l}\text { Livelihood (Family } \\
\text { income generation) }\end{array}$ & $\begin{array}{l}\text { Adaptation to } \\
\text { waterlogging and salinity }\end{array}$ \\
\hline $\begin{array}{l}\text { Combined } \\
\text { cultivation of fish } \\
\text { and hanging } \\
\text { vegetables }\end{array}$ & $\begin{array}{l}\text { Amadi, Bagali and Koyra } \\
\text { unions of Koyra Upazila, } \\
\text { Chadkhali Union of Paikgacha } \\
\text { Upazila under Khulna District } \\
\text { and Borodol Union of } \\
\text { Assasuni Upazila under } \\
\text { Satkhira District }\end{array}$ & $\begin{array}{l}\text { Cultivation of fish and vegetables on the } \\
\text { same piece of swampy land. Hanging } \\
\text { platform is constructed over the swampy land } \\
\text { for vegetable cultivation. A corner of the plot } \\
\text { is raised enough so that it is not inundated by } \\
\text { normal coastal flooding to saw vegetables } \\
\text { seeds. }\end{array}$ & $\begin{array}{l}\text { Livelihood (Family } \\
\text { income generation) }\end{array}$ & $\begin{array}{l}\text { Adaptation to } \\
\text { waterlogging and salinity }\end{array}$ \\
\hline $\begin{array}{l}\text { Purification of } \\
\text { pond water using } \\
\text { govt. supported } \\
\text { filter }\end{array}$ & $\begin{array}{l}\text { Harinagar Village of Amadi } \\
\text { Union at Koyra Upazila of } \\
\text { Khulna District }\end{array}$ & $\begin{array}{l}\text { Govt. (Public Health Engineering } \\
\text { Department-PHED) supported in installing } \\
\text { concrete made water tank and water purifying } \\
\text { filter by which pond water is easily purified } \\
\text { to the extent that can be used for drinking and } \\
\text { other household activities. }\end{array}$ & $\begin{array}{l}\text { Water (purification } \\
\text { and desalinization) }\end{array}$ & $\begin{array}{l}\text { Adaptation to salinity in } \\
\text { ground water and even in } \\
\text { most of the surface water } \\
\text { bodies }\end{array}$ \\
\hline
\end{tabular}

Concrete made two tanks are used to purify water. The bottom of each tank is piled by a The pond water purification few layers. Each layer consists of two pieces

Purification of pond water using traditional knowledge tool is also scattered in the whole coastal region. Example drawn from Harinagar Village of Amadi Union at Koyra Upazila of Khulna District.

$\begin{array}{ll}\text { Aman rice and } & \text { The adaptation technique } \\ \text { fish(Bagda, Golda, } & \text { practiced in Dumuria Upazila } \\ \text { Rui, and katla) } & \text { utilizing waterlogged area and } \\ \text { combined } & \text { Koyra ( particularly in Amadi, }\end{array}$

of net, sand and stone pieces. Water is poured into a tank. After being purified to a considerable degree, the water is taken into another tank for further purification. Water that falls in drops through filter of the latter tank is directly used for drinking and household use

A corner of Aman rice cultivation plot is dug to five to six fit depth and fish fries are released for cultivation. Rice-fish combined cultivation also facilitates irrigation in the
Water (water purification and desalinization)
Adaptation to salinity in ground water and even in most of the surface water bodies
Livelihood (Family income generation)

\section{Adaptation}

waterlogging at Dumuria Upazila and ground water salinity in Koyra 


\begin{tabular}{|c|c|}
\hline culti & $\begin{array}{l}\text { Bagali and Koyra union) and } \\
\text { Shyamnagar upazila } \\
\text { harvesting rainwater }\end{array}$ \\
\hline $\begin{array}{l}\text { Rainwater } \\
\text { harvesting } \\
\text { rectangular } \\
\text { concrete tank }\end{array}$ & $\begin{array}{l}\text { The practice more or less } \\
\text { scattered across the whole } \\
\text { coastal region. Evidence } \\
\text { drawn from Harinagar Village, } \\
\text { Amadi Union, Koyra Upazila } \\
\text { in Khulna District. }\end{array}$ \\
\hline $\begin{array}{l}\text { Directly use of } \\
\text { pond water in } \\
\text { drinking and } \\
\text { household } \\
\text { activities through } \\
\text { proper pond } \\
\text { management }\end{array}$ & $\begin{array}{l}\text { Almost a common practice } \\
\text { found across the whole coastal } \\
\text { region particularly in } \\
\text { Shymnagar Upazila of } \\
\text { Satkhira District, Koyra and } \\
\text { Paikgacha upazila in Khulna } \\
\text { District and Sarankhola } \\
\text { Upazila of Bagerhat District. } \\
\text { Example from Amadi, Bagali } \\
\text { and Koyra unions of Koyra } \\
\text { Upazila }\end{array}$ \\
\hline $\begin{array}{l}\text { Rainwater } \\
\text { harvesting } \\
\text { through hanging } \\
\text { canvas while } \\
\text { raining }\end{array}$ & $\begin{array}{l}\text { Harinagar and other villages of } \\
\text { Amadi Union of Koyra } \\
\text { Upazila }\end{array}$ \\
\hline
\end{tabular}

paddy field from the fish cultivation pond

when necessary. and Shyamnagar upazila

Rainfall on building roof fed into a rectangular concrete tank at a corner of homestead yard and extracting water from the tank for use in drinking and household activities
Scarcity of water for household and drinking purposes
Adaptation to salinity in ground water and even in most surface water bodies.
Taking care and maintenance of Pond e. g. bank heightening, wedding out, removing unnecessary trees and plants from banks and taking extra-care so that intrusion of nothing can deteriorate the water quality and directly use the pond water in drinking and other household purposes.
Scarcity of water for household and drinking purposes
Adaptation to salinity in ground water and even in some surface water bodies
A rectangular shaped concrete tank built in an advantageous point of homestead yard is fed by rainwater that is harvested hanging canvas under the open sky when it is raining and purifying the water by filters installed in the tank.

\section{Scarcity of water} for household and drinking purposes
Adaptation to salinity in ground water and even in some surface water bodies

\begin{tabular}{ll}
\hline \multirow{3}{*}{ Pond Filter } & Harinagar and other villages of \\
& Amadi Union of Koyra \\
& Upazila
\end{tabular}

Rectangular concrete tank set up on pond bank, taking water from pond, poured into tank, purifying by the filter of the tank and using water in household and drinking purposes
Scarcity of water for household and drinking purposes

Adaptation to salinity in ground water and even in some surface water bodies

The practice scattered in

Vegetables different villages of Koyra cultivation on Upazila. Has been a practice raised mound for long in Amadi Union and with concrete wall an emerging practice in $5 \& 7$ no. unions of the upazila.

\begin{tabular}{lll}
\hline Fish vegetables & $\begin{array}{l}\text { Throughout the whole Amadi } \\
\text { and Bagali unions of Koyra }\end{array}$ & $\begin{array}{l}\text { Vegetables like bottle gourd, sweet pumpkin } \\
\text { and creeper vegetable are cultivated in }\end{array}$ \\
combined & Upazila. Evidence drawn from & platform made of net and bamboo erected \\
cultivation & Naksha Village & over fish cultivating pond.
\end{tabular}

Eter Paja

(Household Level Brick-kiln)
Different villages of Amadi Union of Koyra Upazila
Bricks made of the soil derived from homestead fish pond floor and baked with bamboo and other domestic fuel materials.

$\begin{array}{ll}\text { Livelihood } & \begin{array}{l}\text { Adaptation to salinity } \\ \text { and tidal surge }\end{array} \\ \text { generation) } & \end{array}$

Structural

Strengthening

house structure for Adaptation to salinity, improving tropical cyclone and tidal resilience to surge

like cyclone natural disasters
Adaptation to salinity, tidal surge and heavy season erosion during rainy
Gola is a storehouse for grain particularly rice, it is separated from the main house. A circular shaped house made of concrete, bamboo and tin.
Adaptation to pest and insects storehouse for

grain)
Different villages of Amadi Union of Koyra Upazila
Structural 


\begin{tabular}{|c|c|c|c|c|}
\hline $\begin{array}{l}\text { Goalghor } \\
\text { (Cow-shed) }\end{array}$ & $\begin{array}{l}\text { Naksha Village of Amadi } \\
\text { Union at Koyra Upazila under } \\
\text { Khulna District }\end{array}$ & $\begin{array}{l}\text { Bricks covered floor, concrete columns and } \\
\text { walls with so much ventilation and roofing } \\
\text { with Goalpata }\end{array}$ & Structural & $\begin{array}{l}\text { Adaptation to cyclone, } \\
\text { tidal surge and salinity }\end{array}$ \\
\hline $\begin{array}{l}\text { School cum } \\
\text { cyclone shelter }\end{array}$ & $\begin{array}{l}\text { Throughout the whole coastal } \\
\text { zones particularly in Koyra } \\
\text { Upazila of Khulna District, } \\
\text { Shymnagar Upazila of } \\
\text { Satkhira District and } \\
\text { Sarankhola Upazila of } \\
\text { Bagerhat District }\end{array}$ & $\begin{array}{l}\text { Two-storeyed modern complete buildings } \\
\text { with empty ground floor to avert tidal surge. }\end{array}$ & Structural & $\begin{array}{l}\text { Adaptation to cyclone, } \\
\text { tidal surge and salinity }\end{array}$ \\
\hline $\begin{array}{l}\text { Bamboo made } \\
\text { piling }\end{array}$ & $\begin{array}{l}\text { Along the riverbanks of } \\
\text { Kobodak in Amadi Union } \\
\text { particularly at Masjidkur } \\
\text { Village }\end{array}$ & $\begin{array}{l}\text { Bamboo fence placed along the erosion } \\
\text { points of river to protect bank erosion. }\end{array}$ & Structural & $\begin{array}{l}\text { Adaptation to riverbank } \\
\text { erosion }\end{array}$ \\
\hline Bamboo cage & $\begin{array}{l}\text { Along the riverbanks of } \\
\text { Kobodak in Koyra Upazila. } \\
\text { Evidence drawn from } \\
\text { Masjidkur Village of Amadi } \\
\text { Union of the Upazila }\end{array}$ & $\begin{array}{l}\text { Bamboo made square-shaped structure full of } \\
\text { brick-bats placed along erosion points of } \\
\text { river to protect riverbanks. }\end{array}$ & Structural & $\begin{array}{l}\text { Adaptation to riverbank } \\
\text { erosion }\end{array}$ \\
\hline Raising plinth & $\begin{array}{l}\text { Almost in all coastal upazilas } \\
\text { of Bangladesh, evidence from } \\
\text { the whole Koyra Upazila }\end{array}$ & $\begin{array}{l}\text { Plinth generally heightened from } 3-6 \text { feet } \\
\text { high with mud (clay soil) collected from } \\
\text { nearby pond. }\end{array}$ & Structural & $\begin{array}{l}\text { Adaptation to tidal surge } \\
\text { and coastal flooding }\end{array}$ \\
\hline $\begin{array}{l}\text { Lowering house } \\
\text { roof } \\
\text { (Low house) }\end{array}$ & $\begin{array}{l}\text { Almost in all coastal upazilas } \\
\text { of Bangladesh, evidence from } \\
\text { the whole Koyra Upazila }\end{array}$ & $\begin{array}{l}\text { House roof is lowered as much as possible to } \\
\text { avoid the destructive force of strong wind in } \\
\text { cyclone. The coastal houses are of so } \\
\text { low-height that it is very difficult for the } \\
\text { dwellers to stand straight on the floor }\end{array}$ & Structural & $\begin{array}{l}\text { Adaptation to strong } \\
\text { force of cyclone wind }\end{array}$ \\
\hline
\end{tabular}

\begin{tabular}{|c|c|}
\hline $\begin{array}{l}\text { Vegetables } \\
\text { cultivation on the } \\
\text { banks of } \\
\text { homestead fish } \\
\text { pond }\end{array}$ & $\begin{array}{l}\text { Found throughout the whole } \\
\text { Koyra Upazila, seen wide } \\
\text { practice in its Amadi and } \\
\text { Bagali unions }\end{array}$ \\
\hline
\end{tabular}

\begin{tabular}{ll}
\hline Vegetables & $\begin{array}{l}\text { Found throughout the whole } \\
\text { Kultivation on Upazila, particularly } \\
\text { homestead yard } \\
\text { seen wide practice in its Bagali } \\
\text { and Koyra unions }\end{array}$
\end{tabular}

\section{Shrimp}

cultivation

homestead

\begin{tabular}{ll} 
Vegetables & Found particularly at Koyra, 5 \\
cultivation on & no. Koyra, Maharajpur and 7 \\
raised mound at & no. Koyra unions of Koyra \\
homestead & Upazila under Khulna District \\
\hline
\end{tabular}

In seriously (Sidr and Aila)

Rainwater

harvesting affected areas of Khulna and

Satkhira districts, examples

from 5 no. Union of Koyra

Upazila under Khulna District
On the banks of the fish cultivation ponds at homestead, different types of vegetables like bean, bottle gourd, sweet pumpkin radish and red greens are grown.
Livelihood (New income generation)

Adaptation to tidal surge, salinity and land scarcity
On homestead yards, different types of vegetables like bean, bottle gourd, sweet pumpkin radish, red greens and creeper are grown.

On homestead yards, where Sidr and Aila critically hit, shrimp cultivation is practiced as alternative family income source.

In seriously affected areas (by Aila and Sidr), in many homesteads a part of homestead yard is raised enough to grow different types of vegetables

Using coarse sheet of plastic paper over thatched roof to harvest rainwater, storing the rain water into concrete made circular shaped tanks and extracting the water from the tank after being purified by the filter installed in the tank.

\section{Livelihood}

(Meeting domestic needs of vegetables $\&$ new income generation)

\section{Livelihood (post}

Aila generation of income)

\section{Livelihood}

Adaptation to tidal surge,

(Alternative family

income source) salinity intrusion and saline waterlogging

Adaptation to tidal surge, salinity and land scarcity

Adaptation to tidal surge and salinity intrusion

Livelihood

(Alternative family income source)
Adaptation to tidal surge, salinity contamination in surface water bodies and salinity in ground water 


\begin{tabular}{|c|c|c|c|c|}
\hline $\begin{array}{l}\text { Disaster resilient } \\
\text { stronger houses }\end{array}$ & $\begin{array}{l}\text { Modinabad of Koyra Upazila } \\
\text { Sadar Union under Khulna } \\
\text { District }\end{array}$ & $\begin{array}{l}\text { Concrete columns and plinth, roofing by } \\
\text { Goalpata, fencing by bamboo, bran and } G a b \\
\text { juice }\end{array}$ & House structure & $\begin{array}{l}\text { Adaptation to cyclone } \\
\text { and tidal surge }\end{array}$ \\
\hline $\begin{array}{l}\text { Sesame } \\
\text { Cultivation }\end{array}$ & $\begin{array}{l}\text { Harinagar, Hatiadanga, Palbari } \\
\text { and Kinukati villages of } \\
\text { Amadi Union under Koyra } \\
\text { Upazila and Moukhali Village } \\
\text { of Chadkhali Union under } \\
\text { Paikgacha Upazila }\end{array}$ & $\begin{array}{l}\text { Sesame cultivation in paddy fields instead of } \\
\text { Boro Rice cultivation }\end{array}$ & $\begin{array}{l}\text { (Livelihood) Crop } \\
\text { cultivation }\end{array}$ & $\begin{array}{l}\text { Adaptation to salinity in } \\
\text { ground water }\end{array}$ \\
\hline $\begin{array}{l}\text { Sunflower } \\
\text { Cultivation }\end{array}$ & $\begin{array}{l}\text { Harinagar, Hatiadanga, Palbari } \\
\text { and Kinukati villages of } \\
\text { Amadi Union under Koyra } \\
\text { Upazila and Moukhali Village } \\
\text { of Chadkhali Union under } \\
\text { Paikgacha Upazila }\end{array}$ & $\begin{array}{l}\text { Sesame cultivation in paddy fields instead of } \\
\text { Boro Rice cultivation }\end{array}$ & $\begin{array}{l}\text { (Livelihood) Crop } \\
\text { cultivation }\end{array}$ & $\begin{array}{l}\text { Adaptation to salinity in } \\
\text { ground water }\end{array}$ \\
\hline $\begin{array}{l}\text { Lentil (one kind of } \\
\text { pulse) }\end{array}$ & $\begin{array}{l}\text { Harinagar, Hatiadanga, Palbari } \\
\text { and Kinukati villages of } \\
\text { Amadi Union under Koyra } \\
\text { Upazila and Moukhali Village } \\
\text { of Chadkhali Union under } \\
\text { Paikgacha Upazila }\end{array}$ & $\begin{array}{l}\text { Sesame cultivation in paddy fields instead of } \\
\text { Boro Rice cultivation }\end{array}$ & $\begin{array}{l}\text { (Livelihood) Crop } \\
\text { cultivation }\end{array}$ & $\begin{array}{l}\text { Adaptation to salinity in } \\
\text { ground water }\end{array}$ \\
\hline
\end{tabular}

Table 4. Categorization of existing climate change adaptation practices in South-Western coastal area of Bangladesh

\begin{tabular}{llllllll}
\hline & \multicolumn{3}{l}{ Seasonality } & Promoter & \\
\cline { 2 - 5 } Name of the Adaptation practice & DS & WS & LC & GOs & $\begin{array}{l}\text { NGOs and } \\
\text { LC }\end{array}$
\end{tabular}

Livelihood adaptation

CMAS Culture

Grass Cultivation

Keora Nursery

Mele (Reed) Cultivation

Dyke cropping

Cage aquaculture

Crab fattening

Hanging vegetables

Hydroponics

Poultry farming

Cattle Raising

Shrimp-fish mixed cultivation

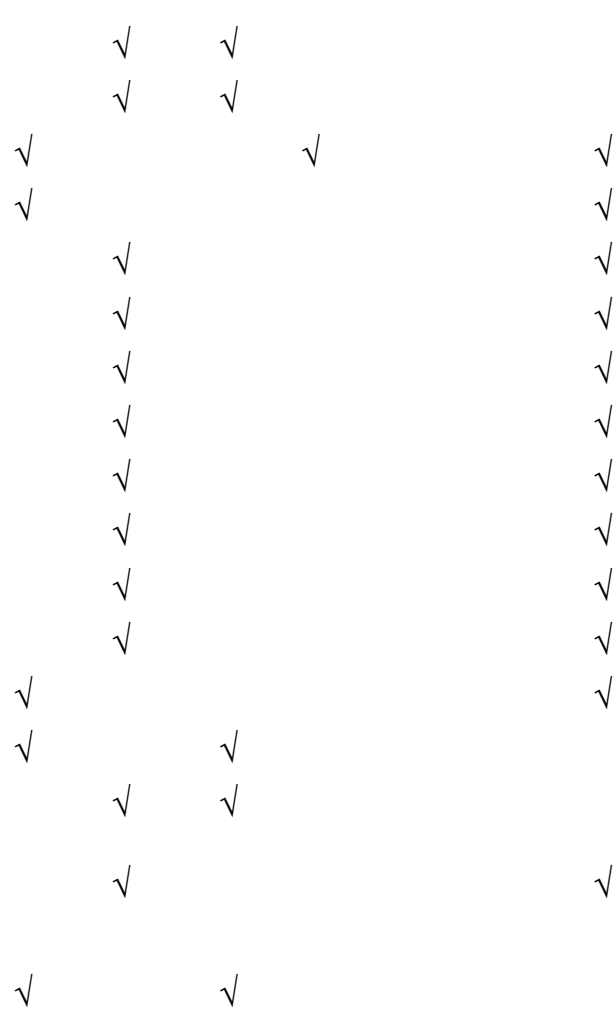

Apiculture

Goalpata Cultivation

Keora Cultivation

Growing local rice variety (BD 28) cultivation by crop calendar adjustment

Local rice variety ( $\mathrm{T}$ Aus) cultivation by crop calendar adjustment 
Cropping on raised mound

Homestead gardening

Combined cultivation of fish and hanging vegetables

Fish vegetables combined cultivation

Vegetables cultivation on raised mound with concrete wall

Aman rice and fish(Bagda, Golda, Rui, and katla) combined cultivation

Vegetables cultivation on the banks of homestead fish pond

Vegetables cultivation on homestead yard

Shrimp cultivation at homestead

Vegetables cultivation on raised mound at homestead

Sesame Cultivation

Sunflower Cultivation

Lentil (one kind of pulse)

Adaptation to Water sector

Rain water harvesting in rectangular concrete tank

Directly use of pond water in drinking and household activities through proper pond management.

Rain water harvesting through hanging canvas while raining

Pond Filter

Purification of pond water using govt. supported filter

Purification of pond water using traditional knowledge

Rain water harvesting

Adaptation to structural sector

Disaster resilient stronger houses

Eter Paja (Household Level Brick-kiln)

Gola ( a granary, a storehouse for grain)

Goalghor (Cow-shed)

School cum cyclone shelter

Bamboo made piling

Bamboo cage

Raising plinth

Lowering house roof (Low house)

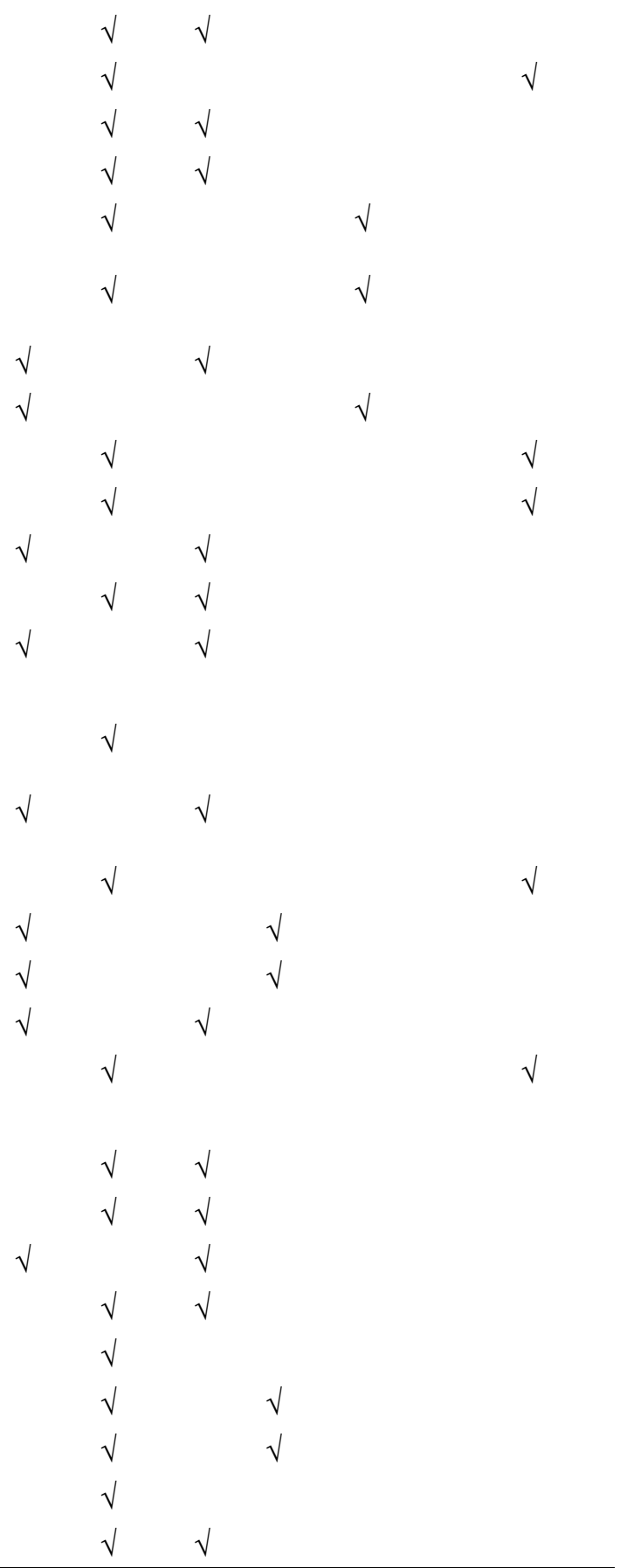

Note: $\mathrm{DS}=$ Dry season, $\mathrm{WS}=$ Wet season, $\mathrm{LC}=$ Local community, GOs $=$ Governmental organizations, NGOs= Non-Governmental Organizations

Source: CARE (RVCC Project), 2010; Satkhira Unnayan Sangstha (SUS), 2009 and Field Survey, 2012 


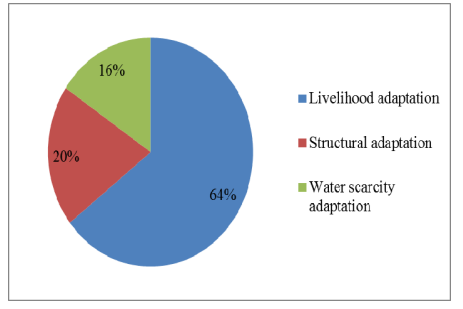

a)

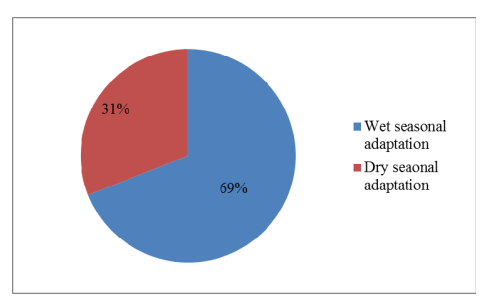

b)

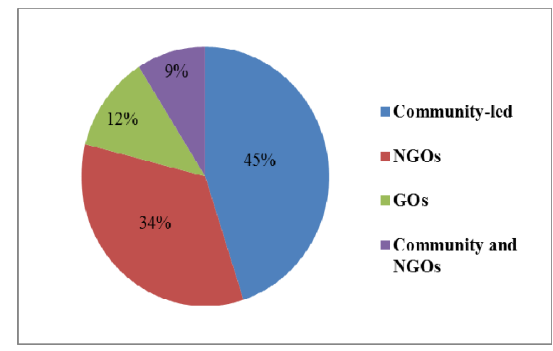

c)

Figure 2. Categorization of existing adaptation practices in SW coastal area of Bangladesh

\subsection{Sustainable Livelihood Adaptation}

Although the local people are adapting various practices in association with governmental fund, donor agencies against water related impacts due to climate change, but all of them are not so popular and successful. The most successful adaptation practice should be socially acceptable, economically viable and environmentally sound. Considering these criteria, the more popular and sustainable adaptation practice for livelihood includes growing local rice variety (BD 28). This is because the practice is well accepted by the all type of community of this reason, initial and additional cost with respect of its derived benefits are very low. Besides this, there is no adverse impact of environment due to exercising this practice. On the other hand, dyke cropping, Keora nursing, homestead gardening, growing vegetables on raised mound etc. are some moderately sustainable livelihood adaptation practices. This study also found that fish vegetables combined cultivation, cage aquaculture, vegetables cultivation on raised mound with concrete wall etc. are some less and unpopular adaptation practices (Table 5).

\subsection{Sustainable Adaptation Practices in Water Sector}

Water is one of the most affected sectors by the adverse impacts of climate change in SW coastal area of Bangladesh. To adapt with this unfavorable condition, local community with the help of government has developed different adaptation practices. Among these practices, this study found that directly use of pond water through proper pond management and rain water harvesting are the more popular and sustainable adaptation practices for the drinking water purpose. The main reason of more sustainability are the very low initial investment and maintenance cost with respect to its perceived benefits. Social acceptance, applicability and environmental soundness are very high. On the other hand, rain water harvesting in rectangular concrete tank and purification of pond water using traditional knowledge are the moderately sustainable practice while Purification of pond water using govt. supported filter and pond filter are the less sustainable (Table 6).

\subsection{Sustainable Adaptation in Structural Sector}

This study found that raising plinth, lowering house roof (Low house) are the more popular and sustainable adaptation practices in structural sector. The very low initial and additional cost for its maintenance compared to its associated benefits, high social acceptance and environmental soundness are the main drivers for these more sustainable adaptation practices. On the other hand, Eter Paja (Household Level Brick-kiln), School cum cyclone shelter, Gola, Goalghor etc. are the moderately sustainable adaptation practices while bamboo made piling and bamboo case are the less sustainable practices (Table 7). 
Table 5. Sustainability of livelihood adaptation practices in SW coastal area of Bangladesh

\begin{tabular}{|c|c|c|c|c|c|}
\hline \multirow[t]{2}{*}{ Name of adaptation practice } & \multicolumn{3}{|c|}{ Sustainability Indicators (Achieved scores) } & \multicolumn{2}{|r|}{ Sustainability } \\
\hline & Social & Economic & $\begin{array}{l}\text { Environmen } \\
\text { tal }\end{array}$ & $\begin{array}{l}\text { Total } \\
\text { average } \\
\text { scores }\end{array}$ & \\
\hline CMAS Culture & 5.0 & 6.0 & 5.5 & 5.50 & Less sustainable \\
\hline Grass Cultivation & 6.75 & 8.67 & 6.0 & 7.13 & Moderately sustainable \\
\hline Mele (Reed) Cultivation & 6.5 & 8.67 & 6.0 & 7.05 & Moderately sustainable \\
\hline Crab fattening & 5.75 & 6.67 & 4.5 & 5.64 & Less sustainable \\
\hline Sunflower Cultivation & 5.25 & 7.33 & 5.0 & 5.86 & Less sustainable \\
\hline Lentil (one kind of pulse) & 8.0 & 8.0 & 6.5 & 7.50 & Moderately sustainable \\
\hline Sesame Cultivation & 6.25 & 8.0 & 5.5 & 6.60 & Moderately sustainable \\
\hline Growing local rice variety (BD 28) & 8.25 & 8.67 & 7.5 & 8.14 & More sustainable \\
\hline $\begin{array}{l}\text { Local rice variety (T Aus) cultivation by } \\
\text { crop calendar adjustment }\end{array}$ & 6.75 & 8.00 & 7.50 & 7.33 & Moderately sustainable \\
\hline Keora Nursery & 5.75 & 7.33 & 5.5 & 6.11 & Moderately sustainable \\
\hline Cattle Raising & 5.25 & 6.67 & 6.5 & 6.14 & Moderately sustainable \\
\hline Dyke cropping & 8.25 & 8.00 & 7.5 & 7.92 & Moderately sustainable \\
\hline Cropping on raised mound & 8.00 & 7.33 & 6.5 & 7.28 & Moderately sustainable \\
\hline Homestead gardening & 7.75 & 8.00 & 7.00 & 7.58 & Moderately sustainable \\
\hline $\begin{array}{l}\text { Combined cultivation of fish and hanging } \\
\text { vegetables }\end{array}$ & 6.00 & 8.00 & 7.5 & 7.17 & Moderately sustainable \\
\hline Aman rice and fish combined cultivation & 5.00 & 6.67 & 6.00 & 5.90 & Less sustainable \\
\hline Shrimp cultivation at homestead & 5.50 & 5.33 & 4.00 & 4.94 & Less sustainable \\
\hline $\begin{array}{l}\text { Vegetables cultivation on raised mound at } \\
\text { homestead }\end{array}$ & 8.25 & 8.00 & 6.5 & 7.58 & \\
\hline Fish vegetables combined cultivation & 4.75 & 6.00 & 6.5 & 5.75 & Less sustainable \\
\hline $\begin{array}{l}\text { Vegetables cultivation on the banks of } \\
\text { homestead fish pond }\end{array}$ & 7.25 & 8.00 & 7.00 & 7.42 & Moderately sustainable \\
\hline Cage aquaculture & 5.00 & 7.33 & 4.00 & 5.44 & Less sustainable \\
\hline Hanging vegetables & 5.75 & 7.33 & 5.5 & 6.19 & Moderately sustainable \\
\hline Hydroponics & 5.5 & 8.00 & 5.00 & 6.17 & Moderately sustainable \\
\hline $\begin{array}{l}\text { Vegetables cultivation on raised mound } \\
\text { with concrete wall }\end{array}$ & 4.5 & 5.33 & 4.5 & 4.78 & Less sustainable \\
\hline Poultry farming & 4.25 & 6.00 & 3.5 & 4.60 & Less sustainable \\
\hline Shrimp-fish mixed cultivation & 3.75 & 6.00 & 3.5 & 4.42 & Less sustainable \\
\hline Keora Cultivation & 5.25 & 6.00 & 7.5 & 6.25 & Moderately sustainable \\
\hline Vegetables cultivation on homestead yard & 7.75 & 8.00 & 6.5 & 7.42 & Moderately sustainable \\
\hline Apiculture & 6.00 & 8.67 & 6.5 & 7.10 & Moderately sustainable \\
\hline Goalpata Cultivation & 5.00 & 8.67 & 7.5 & 7.10 & Moderately sustainable \\
\hline
\end{tabular}

Note: Total average scores $8-10=$ more sustainable, $6-<8=$ moderately sustainable, $4-<6=$ less sustainable 
Table 6. Sustainability of adaptation practices in water sector

\begin{tabular}{|c|c|c|c|c|c|}
\hline \multirow{2}{*}{ Name of adaptation practice } & \multicolumn{3}{|c|}{$\begin{array}{l}\text { Sustainability } \\
\text { scores) }\end{array}$} & \multirow[b]{2}{*}{$\begin{array}{l}\text { Total average } \\
\text { scores }\end{array}$} & \multirow[b]{2}{*}{ Sustainability } \\
\hline & Social & Economic & Environmental & & \\
\hline $\begin{array}{l}\text { Purification of pond water using govt. } \\
\text { supported filter }\end{array}$ & 4.5 & 5.33 & 5.5 & 5.11 & Less sustainable \\
\hline $\begin{array}{l}\text { Purification of pond water using } \\
\text { traditional knowledge }\end{array}$ & 8.25 & 8.70 & 6.5 & 7.82 & $\begin{array}{l}\text { Moderately } \\
\text { sustainable }\end{array}$ \\
\hline $\begin{array}{l}\text { Rain water harvesting in rectangular } \\
\text { concrete tank }\end{array}$ & 6.75 & 8.70 & 6.0 & 7.10 & $\begin{array}{l}\text { Moderately } \\
\text { sustainable }\end{array}$ \\
\hline $\begin{array}{l}\text { Directly use of pond water through } \\
\text { proper pond management }\end{array}$ & 8.50 & 8.70 & 8.0 & 8.40 & More sustainable \\
\hline $\begin{array}{l}\text { Rainwater harvesting through hanging } \\
\text { canvas while raining }\end{array}$ & 7.75 & 9.33 & 7.0 & 8.02 & More sustainable \\
\hline Pond Filter & 5.75 & 6.67 & 8.0 & 6.81 & Less sustainable \\
\hline Rainwater harvesting & 9.5 & 9.67 & 8.5 & 9.22 & More sustainable \\
\hline
\end{tabular}

Note: Total average point $8-10=$ more sustainable, $6-<8=$ moderately sustainable, $4-<6=$ less sustainable

Table 7. Sustainable adaptation in Structural sector

\begin{tabular}{|c|c|c|c|c|c|}
\hline \multirow{2}{*}{ Name of adaptation practice } & \multicolumn{2}{|c|}{$\begin{array}{l}\text { Sustainability } \\
\text { scores) }\end{array}$} & Indicators (Achieved & \multirow[b]{2}{*}{$\begin{array}{l}\text { Total } \\
\text { scores }\end{array}$} & \multirow[b]{2}{*}{ Sustainability } \\
\hline & Social & Economic & Environmental & & \\
\hline $\begin{array}{l}\text { Eter Paja (Household Level } \\
\text { Brick-kiln) }\end{array}$ & 6.00 & 5.33 & 7.5 & 6.28 & $\begin{array}{l}\text { Moderately } \\
\text { sustainable }\end{array}$ \\
\hline $\begin{array}{l}\text { Gola ( a granary, a storehouse } \\
\text { for grain) }\end{array}$ & 7.25 & 8.00 & 7.0 & 7.42 & $\begin{array}{l}\text { Moderately } \\
\text { sustainable }\end{array}$ \\
\hline Goalghor (Cow-shed) & 5.75 & 7.33 & 5.5 & 6.20 & $\begin{array}{l}\text { Moderately } \\
\text { sustainable }\end{array}$ \\
\hline School cum cyclone shelter & 7.50 & 8.00 & 6.5 & 7.33 & $\begin{array}{l}\text { Moderately } \\
\text { sustainable }\end{array}$ \\
\hline Bamboo made piling & 5.75 & 4.00 & 5.5 & 5.08 & Less sustainable \\
\hline Bamboo cage & 7.00 & 4.00 & 5.0 & 5.33 & Less sustainable \\
\hline Raising plinth & 7.50 & 8.00 & 8.0 & 8.5 & More sustainable \\
\hline $\begin{array}{l}\text { Lowering house roof } \\
\text { (Low house) }\end{array}$ & 8.00 & 8.67 & 7.5 & 8.10 & More sustainable \\
\hline Disaster resilient stronger houses & 3.25 & 4.67 & 6.5 & 4.81 & Less sustainable \\
\hline
\end{tabular}

Note: Total average point $8-10=$ more sustainable, $6-<8=$ moderately sustainable, $4-<6=$ less sustainable

\subsection{Seasonal Sustainable Adaptation Practices}

All of adaptation practices around the two seasons, i.e. wet and dry season are not in a similar sustainable level. Some of them are more sustainable and others are moderate and less sustainable. In wet season, growing local 
rice variety cultivation by crop calendar adjustment, raising plinth, lowering house roof, direct rainwater harvesting and rain water harvesting through hanging canvas while raining etc. are the more sustainable adaptation practices while in the dry season (Table 8). Directly use of pond water in drinking and household activities through proper pond management. On the other hand, from the table, it is clear that the number of less sustainable of adaptation practices in wet season is comparatively higher than the dry season.

Table 8. Sustainable adaptation practices in different seasons

\begin{tabular}{|c|c|c|c|}
\hline Seasonality & Name of Practice & $\begin{array}{l}\text { Average } \\
\text { scores }\end{array}$ & Sustainability \\
\hline Wet season & CMAS Culture & 5.50 & Less sustainable \\
\hline & Grass Cultivation & 7.13 & $\begin{array}{l}\text { Moderate } \\
\text { sustainable }\end{array}$ \\
\hline & Aman rice and fish(Bagda, Golda, Rui, and katla) combined cultivation & 5.90 & Less sustainable \\
\hline & Rainwater harvesting in rectangular concrete tank & 7.10 & $\begin{array}{l}\text { Moderate } \\
\text { sustainable }\end{array}$ \\
\hline & Shrimp cultivation at homestead & 4.94 & Less sustainable \\
\hline & Vegetables cultivation on raised mound at homestead & 7.58 & $\begin{array}{l}\text { Moderate } \\
\text { sustainable }\end{array}$ \\
\hline & EterPaja (Household Level Brick-kiln) & 6.28 & $\begin{array}{l}\text { Moderate } \\
\text { sustainable }\end{array}$ \\
\hline & School cum cyclone shelter & 7.33 & $\begin{array}{l}\text { Moderate } \\
\text { sustainable }\end{array}$ \\
\hline & Bamboo made piling & 5.08 & Less sustainable \\
\hline & Dyke cropping & 7.92 & $\begin{array}{l}\text { Moderate } \\
\text { sustainable }\end{array}$ \\
\hline & Cage aquaculture & 5.44 & Less sustainable \\
\hline & Crab fattening & 5.64 & Less sustainable \\
\hline & Hanging vegetables & 6.19 & $\begin{array}{l}\text { Moderate } \\
\text { sustainable }\end{array}$ \\
\hline & Hydroponics & 6.17 & $\begin{array}{l}\text { Moderate } \\
\text { sustainable }\end{array}$ \\
\hline & Poultry farming & 4.60 & Less sustainable \\
\hline & Cattle Raising & 6.14 & $\begin{array}{l}\text { Moderate } \\
\text { sustainable }\end{array}$ \\
\hline & Shrimp-fish mixed cultivation & 4.42 & Less sustainable \\
\hline & Goalghor (Cow-shed) & 6.20 & $\begin{array}{l}\text { Moderate } \\
\text { sustainable }\end{array}$ \\
\hline & Bamboo cage & 5.33 & Less sustainable \\
\hline & Raising plinth & 8.5 & More sustainable \\
\hline & Lowering house roof (Low house) & 8.10 & More sustainable \\
\hline & Keora Cultivation & 6.25 & $\begin{array}{l}\text { Moderate } \\
\text { sustainable }\end{array}$ \\
\hline & $\begin{array}{l}\text { Growing local rice variety (BR 28) cultivation by crop calendar } \\
\text { adjustment }\end{array}$ & 8.14 & More sustainable \\
\hline
\end{tabular}


$\begin{array}{ll}\text { Rainwater harvesting } & 9.22\end{array}$

Disaster resilient stronger houses

Fish vegetables combined cultivation

Cropping on raised mound

Homestead gardening

Combined cultivation of fish and hanging vegetables

Vegetables cultivation on raised mound with concrete wall

Rainwater harvesting through hanging canvas while raining

Dry season Purification of pond water using traditional knowledge

Apiculture

Goalpata Cultivation

Mele (Reed) Cultivation

Local rice variety (T Aus) cultivation by crop calendar adjustment

Purification of pond water using govt. supported filter

Directly use of pond water in drinking and household activities through proper pond management.

Pond Filter

Gola ( a granary, a storehouse for grain)

Vegetables cultivation on the banks of homestead fish pond

Vegetables cultivation on homestead yard

Lentil (one kind of pulse)

Sesame Cultivation

Keora Nursery
4.81

5.75

7.28

4.78

8.02

7.82

6.11
More sustainable

Less sustainable

Less sustainable

Moderate

sustainable

Moderate

sustainable

Moderate

sustainable

Less sustainable

More sustainable

Moderate

sustainable

Moderate

sustainable

Moderate

sustainable

Moderate

sustainable

Moderate

sustainable

Less sustainable

More sustainable

Moderate

sustainable

Moderate

sustainable

Moderate

sustainable

Moderate

sustainable

Moderate

sustainable

Moderate

sustainable

Moderate

sustainable

\subsection{Sustainable Promoter Based Adaptation Practices}

Among the local community-led adaptation practices to climate change, directly use of pond water in drinking and household activities through proper pond management, raising plinth, lowering house roof (Low house) are the more sustainable (Table 9). Most of the other practices are moderate sustainable. This is because of their ecology based traditional knowledge and well-known bio-physical condition of this area. On the other hand, 
growing local rice variety (BD 28) cultivation, rain water harvesting through hanging canvas while raining, rainwater harvesting are the more sustainable adaptation practices promoted by NGOs. By contrary, most of the governmental and government-NGOs adaptation practices are not more sustainable. Unfamiliar of local geo-physical context, very little knowledge about the cultural and traditional knowledge of the local communities are the main reasons behind the comparatively less sustainable adaptation practices promoted by them.

Table 9. Sustainable adaptation practices based on promoter

\begin{tabular}{|c|c|c|c|}
\hline Category & Name of practice & $\begin{array}{l}\text { Average } \\
\text { scores }\end{array}$ & Sustainability \\
\hline \multirow{20}{*}{$\begin{array}{l}\text { Promoted by local } \\
\text { community }\end{array}$} & CMAS Culture & 5.50 & Less sustainable \\
\hline & Grass Cultivation & 7.13 & $\begin{array}{l}\text { Moderate } \\
\text { sustainable }\end{array}$ \\
\hline & Goalpata Cultivation & 7.10 & $\begin{array}{l}\text { Moderate } \\
\text { sustainable }\end{array}$ \\
\hline & Keora Cultivation & 6.25 & $\begin{array}{l}\text { Moderate } \\
\text { sustainable }\end{array}$ \\
\hline & $\begin{array}{l}\text { Local rice variety ( } \mathrm{T} \text { Aus) cultivation by crop calendar } \\
\text { adjustment }\end{array}$ & 7.33 & $\begin{array}{l}\text { Moderate } \\
\text { sustainable }\end{array}$ \\
\hline & Cropping on raised mound & 7.28 & $\begin{array}{l}\text { Moderate } \\
\text { sustainable }\end{array}$ \\
\hline & Combined cultivation of fish and hanging vegetables & 7.17 & $\begin{array}{l}\text { Moderate } \\
\text { sustainable }\end{array}$ \\
\hline & Purification of pond water using traditional knowledge & 7.82 & $\begin{array}{l}\text { Moderate } \\
\text { sustainable }\end{array}$ \\
\hline & $\begin{array}{l}\text { Directly use of pond water in drinking and household } \\
\text { activities through proper pond management }\end{array}$ & 8.40 & More sustainable \\
\hline & Fish vegetables combined cultivation & 5.75 & Less sustainable \\
\hline & Eter Paja (Household Level Brick-kiln) & 6.28 & $\begin{array}{l}\text { Moderate } \\
\text { sustainable }\end{array}$ \\
\hline & Gola ( a granary, a storehouse for grain) & 7.42 & $\begin{array}{l}\text { Moderate } \\
\text { sustainable }\end{array}$ \\
\hline & Goalghor (Cow-shed) & 6.20 & $\begin{array}{l}\text { Moderate } \\
\text { sustainable }\end{array}$ \\
\hline & Raising plinth & 8.5 & More sustainable \\
\hline & Lowering house roof(Low house) & 8.10 & More sustainable \\
\hline & Vegetables cultivation on the banks of homestead fish pond & 7.42 & $\begin{array}{l}\text { Moderate } \\
\text { sustainable }\end{array}$ \\
\hline & Disaster resilient stronger houses & 4.81 & Less sustainable \\
\hline & Sesame Cultivation & 6.60 & $\begin{array}{l}\text { Moderate } \\
\text { sustainable }\end{array}$ \\
\hline & Lentil (one kind of pulse) & 7.50 & $\begin{array}{l}\text { Moderate } \\
\text { sustainable }\end{array}$ \\
\hline & Sunflower Cultivation & 5.86 & Less sustainable \\
\hline
\end{tabular}




\begin{tabular}{|c|c|c|c|}
\hline \multirow{17}{*}{ Promoted by NGOs } & Keora Nursery & 7.11 & $\begin{array}{l}\text { Moderate } \\
\text { sustainable }\end{array}$ \\
\hline & Mele (Reed) Cultivation & 7.05 & $\begin{array}{l}\text { Moderate } \\
\text { sustainable }\end{array}$ \\
\hline & Dyke cropping & 7.92 & $\begin{array}{l}\text { Moderate } \\
\text { sustainable }\end{array}$ \\
\hline & Cage aquaculture & 5.44 & Less sustainable \\
\hline & Crab fattening & 5.64 & Less sustainable \\
\hline & Hanging vegetables & 6.19 & $\begin{array}{l}\text { Moderate } \\
\text { sustainable }\end{array}$ \\
\hline & Hydroponics & 6.17 & $\begin{array}{l}\text { Moderate } \\
\text { sustainable }\end{array}$ \\
\hline & Poultry farming & 4.60 & Less sustainable \\
\hline & Cattle Raising & 6.14 & $\begin{array}{l}\text { Moderate } \\
\text { sustainable }\end{array}$ \\
\hline & Shrimp-fish mixed cultivation & 4.42 & Less sustainable \\
\hline & Apiculture & 7.10 & $\begin{array}{l}\text { Moderate } \\
\text { sustainable }\end{array}$ \\
\hline & Growing local rice variety (BD 28) cultivation & 8.14 & More sustainable \\
\hline & Homestead gardening & 7.58 & $\begin{array}{l}\text { Moderate } \\
\text { sustainable }\end{array}$ \\
\hline & Rainwater harvesting through hanging canvas while raining & 8.02 & More sustainable \\
\hline & Shrimp cultivation at homestead & 4.94 & Less sustainable \\
\hline & Vegetables cultivation on raised mound at homestead & 7.58 & $\begin{array}{l}\text { Moderate } \\
\text { sustainable }\end{array}$ \\
\hline & Rain water harvesting & 9.22 & More sustainable \\
\hline \multirow{6}{*}{$\begin{array}{l}\text { GOs } \\
\text { Both Government and } \\
\text { NGOs }\end{array}$} & Purification of pond water using govt. supported filter & 5.11 & Less sustainable \\
\hline & Pond Filter & 6.81 & $\begin{array}{l}\text { Moderate } \\
\text { sustainable }\end{array}$ \\
\hline & School cum cyclone shelter & 7.33 & $\begin{array}{l}\text { Moderate } \\
\text { sustainable }\end{array}$ \\
\hline & Bamboo made piling & 5.08 & Less sustainable \\
\hline & Bamboo cage & 5.33 & Less sustainable \\
\hline & Rainwater harvesting in rectangular concrete tank & 7.10 & $\begin{array}{l}\text { Moderate } \\
\text { sustainable }\end{array}$ \\
\hline \multirow{3}{*}{$\begin{array}{l}\text { Local community and } \\
\text { NGOs }\end{array}$} & Vegetables cultivation on raised mound with concrete wall & 4.78 & Less sustainable \\
\hline & Vegetables cultivation on homestead yard & 7.42 & $\begin{array}{l}\text { Moderate } \\
\text { sustainable }\end{array}$ \\
\hline & $\begin{array}{l}\text { Aman rice and fish (Bagda, Golda, Rui, and Katla) combined } \\
\text { cultivation }\end{array}$ & 5.90 & Less sustainable \\
\hline
\end{tabular}

\section{Conclusion}

Although the South-Western coastal area of Bangladesh is the worst victim of climate change, the local communities have taken various adaptive measures against these impacts especially in livelihood, water and infrastructural sector. The main finding of this study shows that growing of local rice variety, purification of the pond water through proper pond management, rainwater harvesting, raising plinth, lowering the house roof etc 
are some of the successful and popular adaption practices. However, the civil society, government officials should come forward to strengthen their adaptive capacity and helping to build self reliability. This study will offer an opportunity for the policy makers, donor agencies, government officials to rethink about formulating the adaptation strategies and policies regarding climate change affected people of South Western coastal area of Bangladesh.

\section{Acknowledgement}

The authors would like to thanks all the respondents who had participated in the questionnaire survey. They also acknowledge the kind cooperation of the local people for actively taking into participation in group discussions.

\section{References}

Abbot, J., \& Guijt, I. (1997). Changing views on change: A working paper on participatory monitoring of the environment. Working Paper, International Institute for Environment and Development, London.

Abramovitz, J., Banurui, T., Girot, P. O., Orlando, B., Schneider, N., Spanger-Seigfried, E., ... Hammill, A. (2002). Adapting to Climate Change: Natural resources Management and Vulnerability Reduction. Background Paper to the Task Force on Climate Change, Vulnerable Communities and Adaptation.

Adger, N. W. (2001). Scales of Governance and Environmental Justice for Adaptation and Mitigation. Journal of International Development, 13, 921-931. https://doi.org/10.1002/jid.833

Adger, W. N., Arnell, N. W., \&Tompkins, E. L. (2005). Successful adaptation to climate change across scales. Global Environmental Change, 15, 77-86. https://doi.org/10.1016/j.gloenvcha.2004.12.005

Ahmed, A. U. (Ed.). (2010). Reducing Vulnerability to Climate Change: The Pioneering Example of Community Based Adaptation in Bangladesh. Center for Global Change (CGC) and CARE Bangladesh, Dhaka, p. 156.

Ahmed, A. U., Alam, M., \& Rahman, A. A. (1998). Adaptation to Climate Change in Bangladesh: Future Outlook. In S. Huq, Z. Karim, M. Assaduzzaman, \& F. Mahtab (Eds.), Vulnerability and Adaptation to Climate Change for Bangladesh (pp. 125-143). Kluwer Academic Publishers, Dordrecht.

Alam, M., Nishat, A., \& Siddiqui, S. M. (1998). Water Resources Vulnerability to Climate Change With Special Reference to Inundation. In S. Huq, Z. Karim, M. Asaduzzaman, \& F. Mahtab (Eds.), Vulnerability and Adaptation to Climate Change for Bangladesh (pp. 21-38). Kluwer Academic Publishers, Dordrecht.

BCAS-RA-Approtech. (1994). Vulnerability of Bangladesh to Climate Change and Sea Level Rise: Concepts and Tools for Calculating Risk in Integrated Coastal Zone Management. In Four Volumes (Summary report, Main reports and Institutional report). Bangladesh Centre for Advanced Studies (BCAS), Resource Analysis (RA), and Approtech Consultants Ltd., Dhaka.

Beg, N., Morlot, J. C., Davidson, O., Afrane-Okesse, Y., Tyani, L., Denton, F. ... Rahman, A. A. (2002). Linkages between climate change and sustainable development. Climate Policy, 2, 129-144. https://doi.org/10.1016/S1469-3062(02)00028-1

Breckenridge, R. P., Kepner, W. G., \& Mouat, D. A. (1995). A process for selecting indicators for monitoring conditions of rangeland health. Environmental Monitoring and Assessment, 36, 45-60.

Burton, I. (1992). Adapt and Thrive. Downsview, Ontario: Canadian Climate Centre, unpublished manuscript.

Burton, I. (1996). The growth of adaptation capacity: practice and policy. In J. Smith, N. Bhatti, G. Menzhulin, R. Benioff, M. I. Budyko, M. Campos, ... F. Rijsberman (Eds.), Adapting to Climate Change: An International Perspective (pp. 55-67). Springer- Verlag, New York, NY, USA.

Burton, I. (1996). The growth of adaptation capacity: practice and policy. In J. B. Smith et al. (Eds.), Adapting to Climate Change: An International Perspective (pp. 55-67). New York: Springer.

Burton, I. (1997). Vulnerability and adaptive response in the context of climate and climate change. Climatic Change, 36, 185-196.

Choudhury, G. A. (Ed.). (2011). Climate Change Challenges in Bangladesh. Center for Environmental and Geographic Information Services, pp. 145.

Costanza, R., \& Patten, B. C. (1995). Defining and predicting sustainability. Ecological Economics, 15, 193-196. https://doi.org/10.1016/0921-8009(95)00048-8

Elkington, J. (1998). Cannibals with Forks: The Triple Bottom Line of $21^{\text {st }}$ Century. New Society Publishers: Gabriola Island, BC. 
Empacher, C., \& Wehling, P. (1999). Indikatoren sozialer Nachhaltigkeit. ISOE Diskussionspapiere 13.

Frey, S. D., Harrison, D. J., \& Billett, E. (2000). Environmental Assessment of Electronic Products using LCA and Ecological Footprint. In Joint International Congress and Exhibition, Electronics Goes Green 2000, Berlin, Germany.

Graedel, T. E., \& Klee, R. J. (2002). Getting serious about sustainability. Environ. Sci. Technol., 36, 523-529. https://doi.org/10.1021/es0106016

Hans-Boeckler-Foundation. (Ed.). (2001). Pathways towards a sustainable future. Setzkasten, Düsseldorf.

Harley, M., Horrocks, L., Hodgson, N., \& Minnen, J. (2008). Climate Change: vulnerability and adaptation indicators. Technical paper, European Topic Centre on Air and Climate Change, pp 37.

IPCC. (2007). Climate Change 2007: Synthesis Report. Intergovernmental Panel on Climate Change, Cambridge University Press, Cambridge, UK.

Jörissen, J., Kopfmüller, J., Brandl, V., \& Paetau, M. (1999). Ein Integratives Konzept nachhaltiger Entwicklung. FZ Karlsruhe Research Reports, FZKA 6393, Karlsruhe.

Krugmann, H. (1996). Toward improved indicators to measure desertification and monitor the implementation of the desertification convention. In H. Hambly, \& T. O. Angura (Eds.), Grassroots Indicators for Desertification Experience and Perspectives from Eastern and Southern Africa. International Development Research Centre, Ottawa.

Littig, B. (2001). Zur sozialen Dimension nachhaltiger Entwicklung. Strategy Group Sustainability.

Mandoza, G. A., \& Prabhu, R. (2000). Multiple criteria decision making approaches to assessing forest sustainability using criteria and indicators: a case study. Forest Ecology and Management, 131, 107-126. https://doi.org/10.1016/S0378-1127(99)00204-2

Met Office. (2011). Climate: Observations, Projections and Impacts: Bangladesh. London. UK.

Mitchell, G., May, A., \& McDonald, A. (1995). Picabue: a methodological framework for the development of indicators of sustainable development. International Journal of Sustainable Development and World Ecology, 2, 104-123. https://doi.org/10.1080/13504509509469893

Muniz, I., \& Galindo, A. (2001). Ecological Sustainability and Urban Form. Applied Economics Department, Universitat Auto `noma de Barcelona: Barcelona, Spain.

Nambiar, K. K. M., Gupta, A. P., Fu, Q., \& Li, S. (2001). Biophysical, chemical and socio-economic indicators for assessing agricultural sustainability in the Chinese coastal zone. Agriculture, Ecosystems and Environment, 87, 209-214. https://doi.org/10.1016/S0167-8809(01)00279-1

Nattrass, B., \& Altomare, M. (1999). The Natural Step for Business: Wealth, Ecology and the Evolutionary Corporation. New Society Publishers: Gabriola Island, BC.

Rubio, J. L., \& Bochet, E. (1998). Desertification indicators as diagnosis criteria for desertification risk assessment in Europe. Journal of Arid Environments, 39, 113-120. https://doi.org/10.1006/jare.1998.0402

Smit, B. (Ed.). (1993). Adaptation to Climatic Variability and Change. Guelph: Environment Canada.

Smit, B., Burton, B., Klein, R. J. T., \& Wandel, J. (2000). An Anatomy of Adaptation to Climate Change and Variability. Climatic Change, 45, 223-251.

Smit, B., McNabb, D., \& Smithers, J. (1996). Agricultural adaptation to climate change. Climatic Change, 33, 7-29.

UK Government. (1999). A Better Quality of Life: a Strategy for Sustainable Development for the UK. Cm 4345, The Stationery Office, London.

United Nations Commission on Sustainable Development. (2001). Indicators of sustainable development: framework and methodologies. Background paper No. 3, United Nations, New York.

United Nations Convention to Combat Desertification. (1994). United Nations Convention to Combat Desertification. United Nations, Geneva.

Wackernagel, M., \& Rees, W. (1996). Ecological Footprint: Reducing Human Impact on the Earth. New Society Publishers: Gabriola Island, BC.

Watson, R. T., Zinyoera, M. C., \& Moss, R. H. (1996). Climate Change 1995: Impacts, Adaptations and Mitigation of Climate Change: Scientific-Technical Analysis. Contribution of Working Group II to the 
Second Assessment Report of the Intergovernmental Panel on Climate Change, Cambridge: Cambridge University Press.

World Bank. (2000). Bangladesh: Climate Change and Sustainable Development. Report No. 21104-BD, Rural Development Unit, South Asia Region, The World Bank (WB), Dhaka, pp. 95.

Zhen, L., \& Routray, J. K. (2003). Operational indicators for measuring agricultural sustainability in developing countries. Environmental Management, 32, 34-46.

\section{Copyrights}

Copyright for this article is retained by the author(s), with first publication rights granted to the journal.

This is an open-access article distributed under the terms and conditions of the Creative Commons Attribution license (http://creativecommons.org/licenses/by/4.0/). 